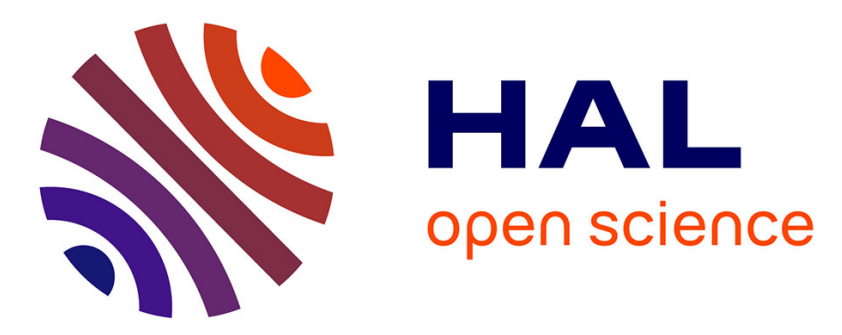

\title{
Isotope evidence for soil organic carbon pools with distinct turnover rates-II. Humic substances
}

Eric Lichtfouse, Sen Dou, Sabine Houot, Enrique Barriuso

\section{To cite this version:}

Eric Lichtfouse, Sen Dou, Sabine Houot, Enrique Barriuso. Isotope evidence for soil organic carbon pools with distinct turnover rates-II. Humic substances. Organic Geochemistry, 1995, 23 (9), pp.845847. 10.1016/0146-6380(95)80005-C . hal-00192675

\section{HAL Id: hal-00192675 \\ https://hal.science/hal-00192675}

Submitted on 29 Nov 2007

HAL is a multi-disciplinary open access archive for the deposit and dissemination of scientific research documents, whether they are published or not. The documents may come from teaching and research institutions in France or abroad, or from public or private research centers.
L'archive ouverte pluridisciplinaire HAL, est destinée au dépôt et à la diffusion de documents scientifiques de niveau recherche, publiés ou non, émanant des établissements d'enseignement et de recherche français ou étrangers, des laboratoires publics ou privés. 
Revised version

Organic Geochemistry 23, 845-847, 1995.

doi:10.1016/0146-6380(95)80005-C

Correspondence: Dr. Eric Lichtfouse, INRA-CMSE-PME, 17, rue Sully, 21000 Dijon, France

Eric.Lichtfouse@dijon.inra.fr

\title{
Isotope evidence for soil organic carbon pools with distinct turnover rates. II. Humic substances ${ }^{\#}$
}

\author{
ÉRIC LICHTFOUSE ${ }^{1 *}$, SEN DOU $^{1+}{ }^{1+}$ SABINE HOUOT ${ }^{2}$ and ENRIQUE BARRIUSO ${ }^{2}$ \\ ${ }^{1}$ Biogéochimie Isotopique, Université Pierre et Marie Curie, Case 120, 75252 Paris Cx 05, France, \\ 2 Institut National de la Recherche Agronomique, Science du Sol, 78850 Thiverval-Grignon, France,
}

\begin{abstract}
Two experiments using ${ }^{13} \mathrm{C}$-enriched substrates have been undertaken to evaluate the relative turnover rates of the main pools of soil organic carbon namely bulk organic carbon, humin and humic acids. Firstly, soil organic matter was labelled naturally during a 5-year field experiment by cultivating Zea mays, a $\mathrm{C}_{4}$ plant, on a soil that had previously grown isotopically distinct $\mathrm{C}_{3}$ plants, e.g. wheat. Secondly, soil organic matter was labelled artificially with either D-glucose or ${ }^{13} \mathrm{C}$-enriched D-glucose during a 21-day laboratory experiment. Isotopic variations observed during both experiments demonstrated the existence of soil carbon pools of decreasing turnover rates: humic acids $>$ bulk organic carbon $>$ humin.
\end{abstract}

Key words - humic acids, humin, carbon-13 labelled soil organic matter

\section{INTRODUCTION}

Humic substances are naturally occurring, heterogeneous organic substances that can be characterized generally as yellow to black in color, of high molecular weight, and refractory (Maillard, 1916, 1917, Schnitzer, 1978, 1991, Ertel and Hedges, 1984, Stevenson, 1985, Aiken et al., 1985, Rice and MacCarthy, 1988, Hayes et al., 1989a, and refs. therein): they are ubiquitous, and are found where organic matter is decomposing in soils, sediments, and waters. Whatever their biological origin, the processes leading to the generation and transformation of humic substances are speculative (Hatcher et al., 1981, 1985, Hayes et al., 1989b, Rice and MacCarthy, 1990, De Leeuw and Hatcher, 1992). For instance, the role of the selective preservation of resistant biopolymers vs. the condensation of small organic molecules, is still open to debate.

Although radiocarbon dating of soil organic matter has provided some information on the temporal sequence of humic substances formation (Paul, 1970, Martel and Paul, 1974, Scharpenseel and Schiffmann, 1977, Campbell, 1978), measurements of mean residence times can be biased by 1) the low precision of ${ }^{14} \mathrm{C}$ dating over relatively short periods, e.g. tens of years, 2) the input of ${ }^{14} \mathrm{C}$ free carbon from fossil fuel consumption (Suess effect), 3) the input of fairly large concentrations

\footnotetext{
\# for $n$-alkanes see Org. Geochem. 22, 349 (1994) and Tetrahedron Lett. 36, 529 (1995).

*Author for correspondence.

+Present address: Departement of Soil Science, Jilin Agricultural University, Changchun, China.
} 
of ${ }^{14} \mathrm{C}$ from bomb testing and by the nuclear industry 4 ) variations in the natural ${ }^{14} \mathrm{C}$ content in different part of the world and 5) isotope discrimination (Paul, 1970, Scharpenseel and Schiffmann, 1977). Hence, turnover determined either by radiocarbon dating or by ${ }^{14} \mathrm{C}$ incubation fails to distinguish clearly the most abundant components of soil organic matter, humin and humic acids (Campbell et al., 1967, Paul, 1970, Martel and Paul, 1974, Scharpenseel and Schiffmann, 1977, Stevenson, 1985). In order to study the turnover of the main pools of soil organic carbon, we have used carbon-13 as a tracer in a long-term field experiment and a short-term laboratory experiment.

\section{EXPERIMENTAL}

Natural labelling: Maize (Zea mays), a $\mathrm{C}_{4}$ plant, was grown in an "experimental" field at La Minière, France, and harvested once per year from a soil previously cultivated with $\mathrm{C}_{3}$ plants. Details on sample setting and mineral content are described elsewhere (Balabane and Balesdent, 1992). Artificial labelling: soil samples from a crop field (Grignon, France) were sterilized with $\gamma$ rays, then incubated for 21 days in the dark at $\mathrm{pF} 2$ at $28^{\circ} \mathrm{C}$ with water from the same field containing either $\mathrm{D}$ glucose $\left(\delta^{13} \mathrm{C}=-10.60 \%\right)$ or ${ }^{13} \mathrm{C}$-D-glucose" $\left(\delta^{13} \mathrm{C} \sim+500 \%\right)$ (Lichtfouse et al., 1995a).

Soil samples (100-120 g) were dried, sieved to $2 \mathrm{~mm}$, finely ground and extracted with $0.1 \mathrm{M} \mathrm{NaOH}\left(48 \mathrm{~h}\right.$ under $\mathrm{N}_{2}$ ) to give an insoluble fraction (humin and minerals) and a soluble fraction (humic and fulvic acids) from which humic acids were separated by precipitation at $\mathrm{pH} 1.5$ with $2.4 \mathrm{M} \mathrm{HCl}(3 \mathrm{x})$. They were further purified by centrifigation at $\mathrm{pH} 7$ to remove most clay particles, dialysed 10 days against distilled water (molecular weight cut-off of dialysis tubes: $2000 \AA$ ) and freeze-dried at $-20^{\circ} \mathrm{C}$. Typical concentrations of bulk organic carbon of soils from La Minière amount to about $9.5 \mathrm{mg}$ of $\mathrm{C}$ per g of dry soil (e.g. Lichtfouse et al., 1995b). Humin and humic acids represent respectively $66 \%$ and $6 \%$ by weight of the bulk soil carbon. Other organic components, such as fulvic acids $(\sim 25 \%$ of bulk $\mathrm{C})$, were not studied here. Isotopic compositions were measured on a Carlo Erba NA 1500 elemental N and C analyser coupled to a VG Sira 10 mass spectrometer: precision $0.03 \%$, overall deviation $0.1 \%$ o (3 replicates). Isotopic compositions are expressed in per mil. relative to the PDB standard: $\delta^{13} \mathrm{C}=\left[\left({ }^{13} \mathrm{C} /{ }^{12} \mathrm{C}\right.\right.$ sample $/{ }^{13} \mathrm{C} /{ }^{12} \mathrm{C}$ std $\left.)-1\right] \times 10^{3}$, where ${ }^{13} \mathrm{C} /{ }^{12} \mathrm{C}$ std $=0.0112372$. 
Table 1. $\delta^{13} \mathrm{C}$ values and percentage of maize-derived carbon (in parentheses) for soil organic components at increasing times of maize cropping. All sampling and analysis have been repeated three times (overall deviation $\pm 0.10 \%$ ). $\delta^{13} \mathrm{C}$ values for $\mathrm{C}_{4}$ soil organic components have been calculated from $\delta_{m}=\delta_{m r}-\delta_{\mathrm{wr}}+\delta_{0}$, where $\delta_{\mathrm{mr}}$ is the isotope values of maize roots $(-12.20 \% \mathrm{o})$ and $\delta_{\mathrm{Wr}}$ is the isotope value of wheat roots $(-27.79 \%$ )

\begin{tabular}{lccc}
\hline $\begin{array}{l}\text { Time } \\
\text { years) }\end{array}$ & Bulk carbon & Humin & Humic acids \\
\hline 0.00 & $-26.27(0.00)$ & $-25.59(0.00)$ & $-27.45(0.00)$ \\
0.42 & $-26.27(0.00)$ & $-25.57(0.13)$ & $-27.35(0.64)$ \\
1.00 & $-26.13(0.90)$ & $-25.40(1.22)$ & $-27.16(1.86)$ \\
1.42 & $-25.92(2.25)$ & $-25.35(1.54)$ & $-26.99(2.95)$ \\
1.75 & $-25.89(2.44)$ & $-25.11(3.08)$ & $-26.79(4.23)$ \\
2.42 & $-25.66(3.91)$ & $-25.19(2.57)$ & $-26.46(6.35)$ \\
3.42 & $-25.10(7.50)$ & $-24.76(5.32)$ & $-26.07(8.85)$ \\
4.00 & $-25.07(7.70)$ & $-24.88(4.55)$ & $-25.66(11.48)$ \\
4.33 & $-24.96(8.40)$ & $-24.66(5.97)$ & $-25.44(12.89)$ \\
& & & \\
\hline
\end{tabular}

\section{Maize field experiment}

\section{RESULTS AND DISCUSSION}

Common terrestrial plants can be classified isotopically in two categories according to their mode of $\mathrm{CO}_{2}$ fixation (Smith and Epstein, 1971, Deines, 1980, O'Leary, 1981). $\mathrm{C}_{3}$ plants incorporate $\mathrm{CO}_{2}$ by ribulose bisphosphate carboxylation (Calvin cycle) and show ${ }^{13} \mathrm{C} /{ }^{12} \mathrm{C}$ isotopic compositions around $-26 \%$. $\mathrm{C}_{4}$ plants fix $\mathrm{CO}_{2}$ by phosphoenol pyruvate carboxylation (Hatch-Slack cycle) and show heavier ${ }^{13} \mathrm{C} /{ }^{12} \mathrm{C}$ isotopic compositions around $-12 \%$. We report here ${ }^{13} \mathrm{C} /{ }^{12} \mathrm{C}$ isotopic compositions of bulk organic carbon, humin and humic acids from soils cultivated with Zea mays, a $\mathrm{C}_{4}$ plant (Table 1). Before maize cultivation (time $=0$ ), humic acids are significantly ${ }^{13} \mathrm{C}$-depleted relative to bulk carbon $(-1.2 \%$ ) and humin $(-1.9 \%$ ). These isotopic differences suggest that humic acids and humin have either different modes of formation or isotopically distinct molecular components, or both.

The soils had been planted previously with $\mathrm{C}_{3}$ plants only. Hence, the ${ }^{13} \mathrm{C} /{ }^{12} \mathrm{C}$ isotopic compositions of the soil organic components increased with time of maize cultivation (Fig.1). Such variations are explained by the input of ${ }^{13} \mathrm{C}$-enriched carbon from maize into soil organic matter. From the isotopic trends, it is obvious that the three components studied incorporate maize-derived carbon at different rates that decrease in the following order: humic acids $>$ bulk organic carbon $>$ humin. These differences can be quantified in three ways.

First, the amount of isotopic increase after 5 crops of maize (4.33 years) shows (Table 1) clearly that humic acids $(+2.0 \%$ ) have incorporated more maize-derived carbon than bulk organic carbon $(+1.3 \%)$ and humin $(+0.9 \%)$. Secondly, we assume that isotopic trends follow a linear law over a short time period, though this might not be true over a longer time period. The slope, calculated by linear regression, thus represents the turnover of each component. It is indeed much higher for humic acids $\left(0.47 \% \mathrm{yr}^{-1}\right)$ than for bulk carbon $\left(0.33 \% \mathrm{yr}^{-1}\right)$ and for humin $\left(0.21 \% \mathrm{oyr}^{-1}\right)$. Thirdly, 
each organic component can be regarded as a mixture from two isotopically distinct $\mathrm{C}_{3}$ and $\mathrm{C}_{4}$ sources (Lichtfouse et al., 1994, Lichtfouse, 1995). At any given time during cultivation, the weight percentage of maize-derived carbon, $\mathrm{M}$, in each component can be calculated from

$$
\mathrm{M}=100\left(\delta-\delta_{0}\right) /\left(\delta_{\mathrm{m}}-\delta_{0}\right) \text { where }
$$

$\delta$ : isotope composition of organic component at a given time of cultivation, $\delta_{0}$ : isotope composition of organic component before maize cultivation (time $=0$ ), $\delta_{\mathrm{m}}$ : isotope composition for $\mathrm{C}_{4}$ soil organic component.

From the calculation of $\mathrm{M}$ for soil organic components at various times of maize cropping (Table 1, Fig.1), it is obvious that the relative amount of maize-derived carbon increases faster for humic acids $\left(3.0 \% \mathrm{yr}^{-1}\right)$ than for bulk carbon $\left(2.1 \% \mathrm{yr}^{-1}\right)$ and for humin $\left(1.4 \% \mathrm{yr}^{-1}\right)$.

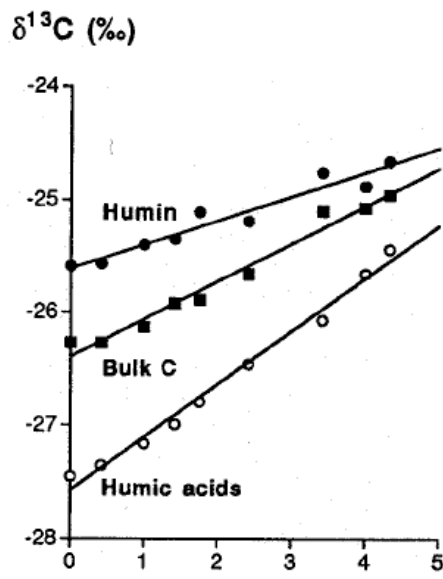

\section{Maize carbon (\%)}

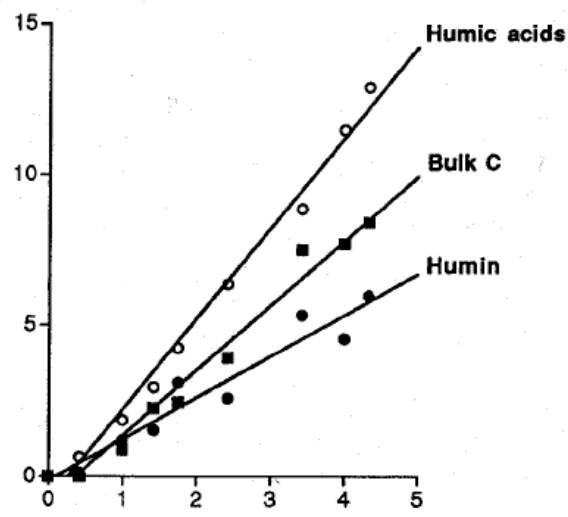

Time of malze cultivation (years)

Figure 1. $\delta^{13} \mathrm{C}$ values (left) and percentage of maize-derived carbon $\mathrm{M}$ (right) for organic components from maize crop soils. $\delta^{13} \mathrm{C}$ linear regression gives (slope, initial value, r): humin $\left(0.212 \% \mathrm{yr}^{-1}\right.$, $25.61 \%$ o 0.97$)$, bulk C $\left(0.334 \% \mathrm{yr}^{-1},-26.39 \%\right.$, 0.99) and humic acids $\left(0.468 \% \mathrm{yr}^{-1},-27.57 \%\right.$ o, 0.99). M linear regression gives: humin $\left(1.362 \% \mathrm{yr}^{-1},-0.130 \%, 0.97\right)$, bulk $\mathrm{C}\left(2.141 \% \mathrm{yr}^{-1},-0.786 \%, 0.99\right)$ and humic acids $\left(3.004 \% \mathrm{yr}^{-1},-0.789 \%, 0.99\right)$. 
${ }^{13} \mathrm{C}$-Glucose laboratory experiment

The fate of carbon incorporated into soil organic components has also been followed by a 3 -week experiment in which soil was incubated with added ${ }^{13} \mathrm{C}$-labelled glucose (Table 2). From the isotope difference between unlabelled glucose and ${ }^{13} \mathrm{C}$-labelled glucose incubation, the decreasing rate of carbon flow is in the order: humic acids $(+6.44 \%$ ) $>$ bulk carbon $(+2.31 \%$ ) $>$ humin $(+1.88 \%$ ) , as observed previously in the maize field experiment.

Table 2. ${ }^{13} \mathrm{C}$ values of organic components for maize crop soils incubated with D-glucose.

\begin{tabular}{lccc}
\hline & $\begin{array}{c}\text { Bulk carbon } \\
(\%)\end{array}$ & $\begin{array}{c}\text { Humin } \\
(\%)\end{array}$ & $\begin{array}{c}\text { Humic acids } \\
(\% \circ)\end{array}$ \\
\hline Glucose & -22.55 & -24.52 & -24.62 \\
13C-Glucose & -20.24 & -22.64 & -18.18 \\
$\delta$ difference & +2.31 & +1.88 & +6.44 \\
\hline
\end{tabular}

\section{CONCLUSION}

Two tracer experiments using carbon-13 at either natural or artificial abundance levels have measured the relative turnover rates of the main pools of soil organic carbon. These rates decrease in the order: humic acids $>$ bulk organic carbon $>$ humin. The use of isotopically distinct pools of organic carbon during the evolution of soil organic matter thus represent a fruitful way to study the dynamics of the degradation of organic matter.

Acknowledgements- We thank Valérie Bergheaud, Jean-Noël Rampon, Micheline Grably and Cyril Girardin for technical assistance and Anne Jaffrezic, Dr. Jérôme Balesdent, Dr. John Jasper for helpful discussions. Two anonymous reviewers are gratefully acknowledged for providing critical and helpful reviews. This work was supported by the Institut National de la Recherche Agronomique. 


\section{REFERENCES}

Aiken G. R., McKnight D. M., Wershaw R. L. and MacCarthy P. (Eds.) (1985) Humic Substances in Soil, Sediment, and Water. Wiley, New York.

Balabane M. and Balesdent J. (1992) Input of fertilizer-derived labelled $\mathrm{N}$ to soil organic matter during a growing season of maize in the field. Soil Biol. Biochem. 24, 89-96.

Campbell C. A. (1978) Soil organic carbon, nitrogen and fertility. In Soil Organic Matter (Edited by Schnitzer M. and Khan S. U.), pp. 173-271. Elsevier, Amsterdam.

Campbell C. A., Paul E. A., Rennie D. A. and McCallum K. (1967) Factors affecting the accurracy of the carbon-dating method in soil humus studies. Soil Science 104, 81-85 and 217-224.

Deines P. (1980) The isotopic composition of reduced organic carbon. In Handbook of Environmental Isotope Geochemistry (Edited by Fritz P. and Fontes J. Ch.), pp. 329406. Elsevier, Amsterdam.

De Leeuw J. W. and Hatcher P. G. (1992) Letter to the Editors responding to "A chemical structure for humic substances" by H.-R. Schulten, B. Plage and M. Schnitzer. Naturwissenschaft. 79, 330-331.

Ertel J. R. and Hedges J. I. (1984) The lignin component of humic substances: distribution among soil and sedimentary humic, fulvic, and base-insoluble fractions. Geochim. Cosmochim. Acta 48, 2065-2074.

Hatcher P. G., Breger I. A., Maciel G. E. and Szeverenyi N. M. (1985) Geochemistry of humin. In Humic Substances in Soil, Sediment, and Water (Edited by Aiken G. R., McKnight D. M., Wershaw R. L. and MacCarthy P.), pp. 275-302. Wiley, New York.

Hatcher P. G., Maciel G. E. and Dennis L. W. (1981) Aliphatic structure of humic acids; a clue to their origin. Org. Geochem. 3, 43-48.

Hayes M. B. H., MacCarthy P., Malcolm R. L. and Swift R. S. (1989a) The search for structure: setting the scene. In Humic Substances II. In Search of Structure (Edited

by Hayes M. B. H., MacCarthy P., Malcolm R. L. and Swift R. S.), pp. 3-31. Wiley, New York.

Hayes M. B. H., MacCarthy P., Malcolm R. L. and Swift R. S. (1989b) Structures of humic substances: the emergence of "forms". In Humic Substances II. In Search of Structure (Edited by Hayes M. B. H., MacCarthy P., Malcolm R. L. and Swift R. S.), pp. 689-733. Wiley, New York.

Lichtfouse É. (1995) ${ }^{13} \mathrm{C}$ Labelling of soil $n$-hentriacontane $\left(\mathrm{C}_{31}\right)$ by maize cultivation. Tetrahedron Lett. 36, 529-530.

Lichtfouse É., Berthier G., Houot S., Barriuso E., Bergheaud V. and Vallaeys T. (1995a) Stable carbon isotope evidence for the microbial origin of $\mathrm{C}_{14}-\mathrm{C}_{18} n$ alkanoic acids in soils. Org. Geochem., in press.

Lichtfouse É., Dou S., Girardin C., Grably M., Balesdent J., Behar F. and Vandenbroucke M. (1995b) Unexpected ${ }^{13} \mathrm{C}$-enrichment of organic components from wheat crop soils: evidence for the in situ origin of soil organic matter. Org. Geochem., in press.

Lichtfouse É., Elbisser B., Balesdent J., Mariotti A. and Bardoux G. (1994) Isotope and molecular evidence for direct input of maize leaf wax $n$-alkanes into crop soils. Org. Geochem. 22, 349-351.

Maillard L. C. (1916) Synthèse des matières humiques par action des acides aminés sur les sucres réducteurs. Ann. Chimie (Paris) 5, 258-317. 
Maillard L. C. (1917) Identité des matières humiques de synthèse avec les matières humiques naturelles. Ann. Chimie (Paris) 7, 113-152.

Martel Y. A. and Paul E. A. (1974) The use of radiocarbon dating of soil organic matter in the study of soil genesis. Soil Sci. Soc. Amer. Proc. 38, 501-596.

O'Leary M. (1981) Carbon isotope fractionation in plants. Phytochem. 20, 553-567.

Paul E. A. (1970) Plant components and soil organic matter. Rec. Adv. Phytochem. 3, 59-104.

Rice J. A. and MacCarthy P. (1988) Comments on the literature of the humin fraction of humus. Geoderma 43, 65-73.

Rice J. A. and MacCarthy P. (1990) A model of humin. Environ. Sci. Technol. 24, 1875-1877.

Scharpenseel H.-W. and Schiffmann H. Z. (1977) Radiocarbon dating of soils, a review. Z. Pflanzenernaehr. Bodenkd. 140, 159-174.

Schnitzer M. (1978) Humic substances: chemistry and reactions. In Soil Organic Matter (Edited by Schnitzer M. and Khan S. U.), pp. 1-64. Elsevier, Amsterdam.

Schnitzer M. (1991) Soil organic matter. The next 75 years. Soil Science 151, 41-58.

Smith B. N. and Epstein S. (1971) Two categories of ${ }^{13} \mathrm{C} /{ }^{12} \mathrm{C}$ ratios for higher plants. Plant Physiol. 47, 380-384.

Stevenson F. J. (1985) Geochemistry of soil humic substances. In Humic Substances in Soil, Sediment, and Water (Edited by Aiken G. R., McKnight D. M., Wershaw R. L. and MacCarthy P.), pp. 13-52. Wiley, New York. 